\title{
Correlates on the Participation of Private Sectors in Local Governance in South Central Mindanao, Philippines
}

\author{
Radzata A. Abdulgani* \\ Office of Administration and Finance \\ Cotabato State University \\ Cotabato City, Philippines \\ *abdulganiradz@yahoo.com
}

\author{
Saidamin P. Bagolong \\ College of Business and Public Administration \\ Cotabato State University \\ Cotabato City, Philippines \\ saidamin_bagolong@ccspc.edu.ph
}

\begin{abstract}
This study aimed to determine the significant correlation between the participation of private sectors in local governance in terms of local pre-qualification bids and awards committee board, local school board, local health board, local development council, and local peace and order council and its attainment of objectives in terms of ensured viability of local autonomy, promotion of development planning, and creation of united and concentrated action on development goal among cities in South Central Mindanao, Philippines. Descriptive-correlation design using purposive sampling to 300 respondents who were members of the boards/councils, utilizing a researcher-made survey questionnaire validated by experts, tested its reliability on alpha Cronbach, and employed Pearson $\mathbf{r}$ correlation. Findings revealed that the Local Pre-qualification Bids and Awards Committee is significantly correlated with the attainment of the private sector participation objectives, such as ensured viability of local governance, promotion of development planning, and unified and concentrated action on development goals. However, the Local Health Board and Local Peace and Order Council do not significantly correlate with ensured viability of local autonomy and creation of united and concentrated action on development goal. The Local Development Council does not significantly correlate with creating a united and focused effort on development goals. Hence, the null hypothesis is partially rejected. The participation of private sectors in the local government's affairs has widened operations to ensure that community needs are met.
\end{abstract}

Keywords-public administration, private sector participation, local governance, descriptive-correlation, Philippines, Asia

\section{INTRODUCTION}

Local governance does not refer to local governments and local populations alone. It includes local and international NGOs, central and local governments, community-based organizations and agencies, the public and the private sector. The strengthening of local governance for growth, poverty reduction, and good governance at the local level is not only a burden or the preservation of local and central government leadership. Private sector leadership has a role to play, given their proximity to the grassroots people, where poverty levels, growth, and bad governance are intense [1].

Republic Act 7160, otherwise known as an "Act providing for the Local Government Code of 1991," mandated the representation of local special bodies such as the local prequalification bids and awards committee, local school board, local health board, local development council, and local peace and order council. It also called for joint ventures and other cooperation mechanisms between the Local Government Unit Entity and the private sector in initiatives or projects dealing with vital services, capacity building, subsistence projects, and local enterprises' creation to increase productivity income [2]. It has also allowed for more effective community governance by institutionalizing people's participation via non-government organizations and civil society [3]

Participation of private sector resources for public financing, construction, operation, and maintenance of development projects typically requires a procurement method that obtains competitive bids for creative services such as architecture, engineering, urban design, urban and regional planning, and fine arts [4]. Consequently, Local authorities do not run schools but provide funds for them and have a range of specific duties and powers about the school system; schools are semi-autonomous and managed and governed by their head teachers and governing bodies. School governing bodies include representatives of the local community, such as the local authority, school staff, and parents; along with local authorities, school governing bodies can be seen to provide democratic accountability [5].

However, private sector funding for health is still a highly contested and controversial topic [6]. The private health sector concluded that considering the resource limitations of current health systems, a more practical approach to expanding access to care is to evaluate and draw on the benefits and expertise of the currently operating private health sector [7,8], and International Finance Corporation [9] as quoted by Yoong et al. [6]. Greater private sector participation might also improve 
equity by allowing governments and the public health system to focus on the poor and underserved [6].

In terms of peace and order, private sector participation in peace varies, such as conflict cost perceptions, degrees of the unity of the pro-peace business faction, and varied access to the policy-making peace process account for significant differences across the cases [10]. Thus, the researchers aimed to determine the correlates on the participation of private sectors in local governance on pre-qualification bids and awards (LPBAC), school board (LSB), health board (LHB), development council (LDC), and peace and order council (LPOC) and its attainment of objectives in terms of ensuring the viability of local autonomy, promotion of development planning, and creation of united and concentrated action of development goal in South Central Mindanao, Philippines.

\section{METHODS}

The study used a descriptive-correlation research design through the survey [11]. This is the most appropriate choice because it used a research questionnaire as a data-gathering instrument in a systematic process. The data gathered were interpreted using statistical tools, making it more accurate [12]. The study was conducted in five local government units in South Central Mindanao, the Philippines, specifically in Cotabato City, General Santos City, Koronadal City, Kidapawan City, and Tacurong City. The study respondents were chosen using purposive sampling, who were members of the Local Pre-qualification Bids and Awards Committee, Local School Board, Local Health Board, Local Development Council, and Local Peace and Order Council as select beneficiaries the residents of the locality. A total of 300 respondents were samples of the study. The sample size was computed using the Raosoft method through computing for 10 percent of the total population. The study utilized a researchermade survey questionnaire using a 5-point Likert scale in gathering information from the respondents. The survey questionnaire was validated by the three experts in the field, with a mean of 4.35 interpreted as a very valid instrument. The reliability evaluation using Cronbach's Alpha method was used, which revealed a result of 0.879 described as highly reliable. The study employed the Pearson r Correlation to determine the relationship between private sectors' participation in local governance and its attainment of objectives.

\section{RESULTS}

As presented in Table 1 are the results of the data on the correlation between the participation of the private sectors and its attainment of objectives in local governance in South Central Mindanao, Philippines, which revealed that objective one on ensured viability of local autonomy is positively correlated with local pre-qualification bids and awards committee, local school board, and local peace and order council with an R-values of $0.252,0.243$, and 0.050 respectively and described as the high significance of 0.000 .
TABLE I. CORRELATION MATRIX ON THE PARTICIPATION OF PRIVATE Sectors in Local Governance in South Central MindanaO, PHILIPPINES

\begin{tabular}{|c|c|c|c|c|c|c|}
\hline \multirow{3}{*}{$\begin{array}{c}\text { Predicto } \\
\text { rs }\end{array}$} & \multicolumn{6}{|c|}{ Attainment of Objectives in Local Governance } \\
\hline & \multicolumn{2}{|c|}{$\begin{array}{c}\text { Ensured } \\
\text { viability of } \\
\text { local autonomy }\end{array}$} & \multicolumn{2}{|c|}{$\begin{array}{c}\text { Promotion of } \\
\text { development } \\
\text { planning }\end{array}$} & \multicolumn{2}{|c|}{$\begin{array}{l}\text { Creation of united } \\
\text { and concentrated } \\
\text { action on } \\
\text { development goal }\end{array}$} \\
\hline & $R$ & Sig & $R$ & Sig & $\boldsymbol{R}$ & Sig \\
\hline LPBAC & $\begin{array}{l}0.252 * \\
*\end{array}$ & $\begin{array}{l}0.00 \\
0\end{array}$ & $\begin{array}{l}0.223^{*} \\
*\end{array}$ & $\begin{array}{l}0.00 \\
0\end{array}$ & $-0.131 *$ & 0.023 \\
\hline LSB & $\begin{array}{l}0.243 * \\
*\end{array}$ & $\begin{array}{l}0.00 \\
0\end{array}$ & $-\overline{0.136^{*}}$ & $\begin{array}{l}0.01 \\
8\end{array}$ & $0.187 * *$ & 0.001 \\
\hline LHB & 0.074 & $\begin{array}{l}0.19 \\
9\end{array}$ & $0.127 *$ & $\begin{array}{l}0.02 \\
8 \\
\end{array}$ & -0.057 & 0.325 \\
\hline LDC & $\begin{array}{l}0.346^{*} \\
*\end{array}$ & $\begin{array}{l}0.00 \\
0\end{array}$ & $0.148^{*}$ & $\begin{array}{l}0.01 \\
0\end{array}$ & -0.079 & 0.175 \\
\hline LPOC & 0.050 & $\begin{array}{l}0.39 \\
0 \\
\end{array}$ & $\begin{array}{l}0.245^{*} \\
*\end{array}$ & $\begin{array}{l}0.00 \\
0 \\
\end{array}$ & 0.071 & 0.218 \\
\hline
\end{tabular}

*Significant at the .05 level (Significant)

Similarly, on objective 2, promotion of development planning is highly correlated local pre-qualification bids and awards committee and local peace and order council with Rvalues of 0.223 and 0.245 , respectively, and described as the high significance of 0.000 . The local school board, local health board, and local development council appeared to correlate with R-values of $-0.136,0.127$, and 0.148 or the significance of $0.018,0.028$, and 0.010 .

Further, it can be observed that on objective 3, the creation of united and concentrated action on development goal exhibited a high correlation for the local school board with an $\mathrm{R}$-value of 0.187 described as the increased significance of 0.001. Still, on local pre-qualification bids and awards, the committee is correlated with an R-value of -0.131 , indicating the significance of 0.023 .

\section{DISCUSSION}

Results revealed that there is a high correlation between objectives of the local governance in terms of ensured viability of local autonomy, promotion of development planning, and creation of unified and concentrated action on development goals about local pre-qualifications bids and awards committee, local school board, local health board, local development council, and local peace and order council which implies that private sector participation has progressively developed in all its forms an essential aspect of local autonomy [13,14].

Lyons, Smuts, and Stephens [14] find private sector participation has a significant effect on development, which Friedmann [15] calls "socially sustainable conditions." The discourse of private sector participation has become the common denominator of action for development agencies globally [16] as cited by Islam, Siti Hajar Abu Bakar, and Wahab [17]. Private sector participation is primarily concerned with influencing policy-making processes to achieve an outcome as close as possible to their ideal position [18]. 
Recent trends toward participatory governance and private sector participation have enabled ordinary community members to be more involved in procurement plans, procurement, and processing of contracts [19]. With the private sector participation, government-to-third-party contracts such as vendors and contractors or service providers have been transparent. If accountability exists, elected authorities are responsible for their conduct through the use of available resources can be ensured [20].

It is essential to recognize the impact of local autonomy on public Procurement [21]. If the private sectors can be involved in any or all stages of project planning, procurement, and implementation, there would be greater ownership of the project. The principle of private sector participation is embodied in the 1987 Philippine Constitution [22], the Local Government Code [23], and the Government Procurement Act [24].

Further, citizens' access to public schools can be restricted by the bureaucratic and technocratic culture of school districts and private sector participation. The challenge of assuring that the school board can represent the citizenry on behalf of children's greater good and work effectively toward increased student achievement warrants review [25].

Despite its strong private sector participation on local school board as evidently shown in the result, regional autonomy has raised some concerns on the deterioration of quality of primary education with far-reaching effects on the country's future, general lack of awareness about the current state of public education among stakeholders, weak planning and budgeting practices and processes that contribute to inefficient and ineffective use of local education funds, lack of transparency and accountability in the administration of the public school system, and among others [26].

According to Southeast Asia Technology and Transparency Initiative [27], Local School Board is not always functional in every town, city, and province. Proper planning, utilization, and monitoring of the education fund rely on a functioning Local School Board. There is a need for continued advocacy with the Department of Interior and Local Government to ensure compliance of LGUs. The Local School Board is one avenue that private sectors and other civil societies can influence how education funds are spent at the local level.

Bohnstengel [28] opined that local school boards had gained more credibility, especially as school districts' financial situation has become more tenuous. It becomes incumbent upon the charter schools to address these concerns by producing consistent and effective leadership and management leadership linked to improved student performance data. If this is done, the school can establish credibility among all the stakeholders and be deemed successful by any external performance review team.

Local autonomy impacts its communities by keeping the violence down, solving community problems, and empowering local actors to become peace builders [29]. This is why the local government units reconstituted the Local Peace and Order Council to help pursue a peaceful and progressive community. They are tasked with developing strategies and recommendations for steps to strengthen or improve peace and order, oversee peace and order programs and projects, and the operation of civilian volunteers, self-defense organizations, and other counter-insurgency programs, among others [30].

As mentioned, Ahmad, Ullah, and Muhammad [31] noted that transforming the causes and consequences of conflictprivate sectors play a role in promoting structural transformation to address root causes of armed conflict; demilitarizing minds, healing psyches, and fostering reconciliation by involving local civil society actors and framing DDR as part of community needs (thereby increasing its chance of success); (4) transforming values and cultures mainly through education for peace [32]

Thus, private sectors' participation in public management has promoted development planning, as this is a crucial dimension of good governance [33]. Local autonomy involves changes in the relationship between local government units and the participation of private sectors in the local provision of boards/councils for public goods [34-36], then its local governance is very high [37].

\section{CONCLUSION}

The participation of private sectors is perceived to be conduits between the citizens and the local government. The participation of private sectors in local governance can improve the communities and influence the provision of benefits to needy residents. On the part of the government, the services foreseen include reducing responsibilities because some responsibilities will be shouldered by the private sectors and improved the quality of public policies. After all, private sectors come from the public and therefore know what the general needs. In the private sector, they can widen their operations and influence and participate in development activities. The study revealed that the private sectors join in public affairs from planning down to implementing, monitoring, and evaluating the local governments' projects and programs to ensure that the community's basic needs are met. Hence, any development planning initiative's success depends on how the unique local bodies can create a sense of commonality among private sectors to produce the collaboration necessary for its realization [38].

\section{REFERENCES}

[1] D. Satterthwaite and D. Mitlin, (Eds.). Empowering Squatter Citizen:" Local Government, Civil Society and Urban Poverty Reduction". London, UK: Routledge, 2013.

[2] P.E. Legaspi, "Changing the function of a decentralized state's local government: the Philippines example," Public Management Review, vol. 3 , no. (1), pp. 131-9, 2001 
[3] N. Banks and D. Hulme, "The role of NGOs and civil society in development and poverty reduction," Brooks World Poverty Institute Working Paper, no. (171), pp. 1-39, 2012.

[4] A. Engelbert, N. Reit, and L. Westen, "Procurement Methods in Kenya A Step Towards Transparency?" European Procurement \& Public Private Partnership Law Review, vol. 7, no. (3), pp. 162-171, 2012.

[5] A. West and P. Currie, "The role of publicly funded education in England in the private sector: finance, supply, and Decision-Making," Policy and Politics, vol. 36, no. (2), pp. 191-207, 2008.

[6] J. Yoong, N. Burger, C. Spreng, and N. Sood, "Private sector participation and health system performance in sub-Saharan Africa," PLoS One, vol. 5, no. (10), p. e13243, 2010.

[7] P.A. Berman, "Rethinking health care systems: Private health care provision in India," World Development, vol. 26, no. (8), pp. 1463-79, 1998.

[8] A.S. Preker and A.L. Harding, editors. Private participation in health services. US: The World Bank, 2003.

[9] International Finance Corporation, The health business in Africa: Partnering for improving people's lives with the private sector. Washington (District of Columbia): International Finance Corporation, 2007.

[10] A. Rettberg, "El Salvador, Guatemala and Colombia* Private sector and peace," Journal of Latin American Studies, vol. 39, no. (3), p. 463, 2007.

[11] B. Johnson and J. Christensen, Educational research ( $3^{\text {rd }}$ ed.). Thousand Oaks, CA: SAGE, 2008

[12] P.D. Leedy and J.E. Ormrod, Practical research. Vol. 108. Saddle River, NJ: Pearson Custom, 2005.

[13] D. Mitlin and J. Thomson, "Participatory approaches in urban areas: Strengthening civil society or reinforcing the quo?" Environment and Urbanization, vol. 7, no. (1), pp. 231- 250, 1995.

[14] M. Lyons, C. Smuts, and A. Stephens, "Participation, empowerment, and sustainability: (how) do the links work?" Urban Studies, vol. 8, pp. 1233-1251, 2001

[15] J. Friedmann, "Rethinking poverty: Empowerment and citizen right," International Social Science Journal, vol. 148, pp. 161-172, 1996.

[16] F. Tembo, "NGDOs' role in building poor people's capacity to benefit from globalization," Journal of International Development, vol. 16, pp. 1023-1037, 2004

[17] M.R. Islam, Siti Hajar Abu Bakar Ah, and H.A. Wahab, "Local Knowledge in the Lips of Globalization: Uncertainty of Community Participation in NGO Activities," Revista De Cercetare Si Interventie Social, vol. 43, no. (12), pp. 7-23, 2013.

[18] H. Klüver, European Union lobbies. Lobbying, Interest Groups and Policy Changes. Oxford: oxford University Press, 2013.

[19] S. Fukuda-Parr and C. Lopes, editors. Production capacity: new ideas for old issues. London, UK: Routledge, 2013.

[20] A. Cornwall, H. Lucas, and K. Pasteur, "Introduction: accountability through participation: developing workable partnership models in the health sector," IDS Bulletin, vol. 31, no. (1), pp. 1-13, 2000.
[21] M. Halaskova, "Procuring public services and the role of territorial selfgovernment," Proceedings of the 18th International Colloquium on Regional Sciences, Brno: Masaryk University, 2015, pp. 367-374.

[22] R.S. Lazo, Philippine governance and the 1987 Constitution. Philippines: Rex Bookstore, Inc., 2009.

[23] A.Q. Pimentel, The 1991 Code of Local Government: the guide to national growth. Mandaluyong: Cacho Publishing House, 1993.

[24] M.K.V. Pimentel, "Procurement Watch, Inc.: The role of civil society in public procurement reforms in the Philippines," Challenges in public procurement: An international perspective, pp. 37-47, 2005.

[25] M.C. Dunn, School Board Service: How Modern School Board Members Engage and Understand their Leadership Role. Order No. 3382090, Washington: Washington State University, 2009.

[26] J.M. Robredo and N.C. Mayor, Reinventing local school boards in theThe Philippines. PowerPoint Presentation, 2008.

[27] Southeast Asia Technology and Transparency Initiative, Capacity Building of Local School Boards to Utilise Special Education Fund Data. E-Net Philippines with support from Open Data Lab Jakarta under the Open Data for Transparency, 2015.

28] R.E. Bohnstengel, Leadership and Autonomy: An Examination of the Governance and Management Practices of Four Charter Schools in Charleston, South Carolina. Order No. 3507848, Columbia: University of South Carolina, 2012.

[29] P. Van Tongeren, "Potential cornerstone of infrastructures for peace? How local peace committees can make a difference," Peacebuilding, vol. 1, no. (1), pp. 39-60, 2013.

[30] MENA Report, Philippines: Ifugao Town Reconstitutes Local Peace and Order Council. MENA Report, 2016.

[31] N. Ahmad, F. Ullah, and N. Muhammad, "Community Based Peace Building In A Fragile Context." New Horizons, vol. 11, no. (2), pp. 95110, 2017.

[32] S. Iglesias, "The role of civil society in peacebuilding: Southeast Asia in focus," Paper for Civil Society Dialogue Network (CSDN) Meeting at Brussels, vol. 7, 2013

[33] A.B. Brillantes and J.O. Sonco, "Harmonizing national and sub-national objectives and outcomes by citizen commitment and capacity building (Special References to the Philippines)," In Fiscal Equalization, Boston, MA: Springer, 2007, pp. 95-128.

[34] R.A. Rhodes, "The new governance: governing without government," Political studies, vol. 44, no. (4), pp. 652-67, 1996

[35] B. Denters and LE. Rose, (Eds), Comparing Local Governance: Trends and Developments. Basingstoke: Palgrave Macmillan, 2005.

[36] H. Reynaert, "Comparing local governance," Trends and developments, pp. 121-123, 2008.

[37] K. Nicolas, "Does Local Autonomy Facilitate Local Government Reform Initiatives? Evidence from Switzerland." The Public secto management International Journal, vol. 31, no. (4), pp. 426-447, 2018.

[38] C.S. Thompson, "'School Administrators' and Stakeholders' Attitudes toward, and Perspectives on, School Improvement Planning," Educational Planning, vol. 25, no. (4), pp. 7-26, 2018 